\title{
Prefrontal lobotomy on Evita was done for behavior/ personality modification, not just for pain control
}

\author{
Daniel E. Nijensohn, MD, MSc, PhD \\ Department of Neurosurgery, Yale University School of Medicine, New Haven, Connecticut
}

Eva Perón, best known as Evita, underwent a prefrontal lobotomy in 1952. Although the procedure was said to have been performed to relieve the pain of metastatic cancer, the author carried out a search for evidence that suggests that the procedure was prescribed to decrease violence and to modify Evita's behavior and personality, and not just for pain control.

To further elucidate the circumstances surrounding the treatment of this well-known historic figure, the author reviewed the development of the procedure known as prefrontal lobotomy and its three main indications: management of psychiatric illness, control of intractable pain from terminal cancer, and mind control and behavior/personality modification. The role of pioneering neurosurgeons in the development of prefrontal lobotomy, particularly in Connecticut and at Yale University, was also studied, and the political and historical conditions in Argentina in 1952 and to the present were analyzed.

Evita was the wife of Juan Perón, who was the supreme leader of the Peronist party as well as president of Argentina. In 1952, however, the Peronist government in Argentina was bicephalic because Evita led the left wing of the party and ran the Female Peronist Party and the Eva Perón Foundation. She was followed by a group of hardcore loyalists interested in accelerating the revolution. Evita was also suffering from metastatic cervical cancer, and her illness increased her anxiety and moved her to purchase weapons to start training workers' militias. Although the apparent purpose was to fight her husband's enemies, this was done without his knowledge. She delivered fiery political speeches and wrote incendiary documents that would have led to a fierce clash in the country at that time.

Notwithstanding the disreputable connotation of conspiracy theories, evidence was found of a potentially sinister political conspiracy, led by General Perón, to quiet down his wife Evita and modify her behavior/personality to decrease her belligerence, in addition to treating her cancer-related pain. Psychosurgery was purportedly intended to calm Evita and thus avoid a bloody civil war in Argentina. It was carried out in maximum secrecy and involved a distinguished American neurosurgeon, Dr. James L. Poppen, from the Lahey Clinic in Boston. A recorded and videotaped interview with a former scrub nurse and confidante of Dr. James L. Poppen revealed that prior to the lobotomy on Eva Perón, he performed lobotomies on a few prisoners in the prison system in Buenos Aires. Later, Dr. Poppen seems to have regretted his involvement and participation in this sad chapter in Argentine history.

The treatment of Evita at the end of her life was influenced by extraordinary circumstances of time and place but also involved general issues of medical professionalism, the ethics of neuroscience, and the risks of being manipulated by labyrinthine byzantine politics. This story serves as a reminder that any physician, even one considered to be one of the best in the world, may act naively and become a pawn in a game he cannot begin to fathom.

http://thejns.org/doi/abs/10.3171/2015.3.FOCUS14843

KEY WORDS Eva Perón; Evita; prefrontal lobotomy; leukotomy; intractable pain from cancer; violent agitated behavior; behavior/personality modification; mind control; James L. Poppen; medical professionalism; ethics of neuroscience; Argentine history

$\mathrm{M}$ ARía Eva Ibarguren-Duarte de Perón, best known as Evita (1919-1952), is a well-known figure of the 20th century, as well as a myth. Her death on July 26, 1952, at age 33, childless and at the peak of her power, caused great commotion in Argentina and the rest of the world. Details of her illness, treatments, and death have been slowly emerging. In addition to pain and sorrow, the story is full of lies, deceit, secrets, and misinformation. ${ }^{2,3}$ In 2011, together with a group of collaborators, I reported new evidence regarding a prefrontal lobotomy

SUBMITTED December 10, 2014. ACCEPTED March 23, 2015.

INCLUDE WHEN CITING DOI: 10.3171/2015.3.FOCUS14843.

DISCLOSURE The author reports no conflict of interest concerning the materials or methods used in this study or the findings specified in this paper. 
performed during the last months of Evita's illness. ${ }^{13,14}$ We confirmed the shocking claim of the internationally known neurosurgeon Dr. George Udvarhelyi, who was a member of Eva Perón's medical team, that she underwent a prefrontal lobotomy before her death. ${ }^{15}$ Review of skull radiographs showed findings compatible with trephinations, and neurosurgeon Dr. James L. Poppen from Boston was identified as the surgeon who performed the procedure. ${ }^{18}$ Dr. Edward R. Laws, Jr., Udvarhelyi's favorite student and one of my mentors at the Mayo Clinic, played an important role in this investigation. Articles published in peer-reviewed journals were followed by worldwide media response (The Telegraph, Connecticut Post, New York Times, El Clarín, La Nación, InfoBaea, Los Andes, Diario Uno, El Universal, Le Figaro, and others). The surgery appears to have taken place in June 1952 at the presidential palace in Buenos Aires. New testimony has confirmed the above (Y. Beamer, letter to Dr. Daniel E. Nijensohn, personal collection, July 18, 2012). ${ }^{3}$

The treatment of illnesses suffered by political leaders and heads of state is often kept secret from the public and from medical science. Uncovering these secrets gives us an opportunity to understand the evolution of therapeutic fashions and the impact neurosurgical events can have on the course of history. Information regarding the lobotomy performed on Eva Perón was kept as a state secret, a status reinforced by the apparatus of the Argentine state, and thus its revelation has been a slow and difficult process. ${ }^{2,3}$ The possibility that a lobotomy was performed for indications other than control of intractable pain from metastatic cervical cancer has been a source of concern. ${ }^{3}$ Careful review of Argentine history reveals that Evita exhibited anxious and agitated bellicose behavior that led to a reactive conspiracy to quiet her through psychosurgery. Although it can be argued that the political reasons were mainly to avoid a bloody civil war, the use of neurosurgery to control behavior, change personality, and decrease belligerence for the benefit of the state rather than the patient is contrary to accepted principles of medical professionalism and ethics of neuroscience, even when considering that these events took place before the Belmont Report outlining ethical principles and guidelines for the protection of human subjects in 1979.11

\section{The Development of Prefrontal Lobotomy}

The procedure known as prefrontal lobotomy or leukotomy was developed by individuals who performed pioneering work in psychosurgery, including Egas Moniz (1874-1955) and Pedro Almeida Lima (1903-1985) in Portugal, John Fulton (1899-1960) and others at Yale University and other institutions in Connecticut, and James L. Poppen (1903-1978) in Boston., ${ }^{912,20}$

Prefrontal lobotomy was initially proposed as treatment of psychiatric illness (prior to the development of effective alternatives such as chlorpromazine [Thorazine] in 1953). ${ }^{12,20}$ It was also performed in selected patients with intractable pain, mostly cancer related. ${ }^{5,20,22}$ Up to $60 \%$ of patients exhibited a good response after lobotomy. Pain relief itself might not have been achieved, but a lack of emotional response was apparent. Patients would no longer seem to care, even if they continued to suffer from pain. In addition, prefrontal lobotomy was used for control of aggression, violence, and belligerence.

\section{Evita's Role in Peronist Argentina}

Evita's relationship with her husband Juan Perón is key to understanding her power. According to Loris Zanatta in Eva Perón, Una Biografía Política, Evita's political birth started earlier than is commonly accepted, and was parallel to that of Perón. ${ }^{23}$ There was an inevitable and growing competition between them. Argentina's Peronism was bicephalic, because Evita shared power with her husband. Her role was certainly not one of subordination or dependency, as many obstinately continue to repeat. Her place in the movement and its history is wider and more nuclear than commonly acknowledged. She acted aggressively and managed to impose her own people on her husband's circle. She was furiously anti-American, unlike her husband who waxed and waned on this subject. Both had differing positions regarding the Roman Catholic Church and religious education in public schools. In 1947, Evita achieved one of her greatest triumphs when she pushed the Argentine Congress to approve a bill giving women the right to vote. She became the strongest defender of the Peronist doctrine, but her approach was more radical, giving rise to Evitism within Peronism. She was simultaneously worshipped by her supporters and hated by her opponents. In 1950, when Argentina's wealth started to fade, Perón insisted on austerity measures, while she opposed them. Evita was impetuous, while Juan Perón was a very controlled individual. Only on very few occasions did he lower his guard and allowed ire to permeate a speech or decision-making process. Perón concentrated his efforts on political maneuvering, accomplishing the 1949 constitutional reform that, among other things, allowed him to be reelected. He monopolized all media, and the political propaganda of the Peronist party was asphyxiating and omniscient. Evita was in charge of the government's social policies, heading departments with enormous budgets, none more so than the Eva Perón Foundation.

Evita also took an active role in constitutional reform in Argentina. Rumors started to circulate that she had ambitions to seek elected office, specifically coveting the vice-presidential candidacy on her husband's ticket in the 1951 elections. The "Renunciamiento,",3 the moment she declined the vice-presidential spot in Perón's reelection campaign ticket, has been explained in many different ways. It seems that it was Perón who refused to encourage her to pursue that political office. Although Juan and Evita were advertised as a loving couple (Fig. 1), the historical evidence suggests otherwise ${ }^{17}$ (Fig. 2). There was a significant age difference between them and, more importantly, they had very different personalities. As a military man, he was an early riser and went to bed early as well. His life was regimented and he was disciplined. He was very punctual and obsessive about his personal appearance and cleanliness. Eva led a very different life. She was habitually late. He prided himself on being an intellectual and was fluent in German, Italian, and Spanish, and his background was that of a professor of the military college. He liked to quote the classics. Evita, on the other hand, never completed high school, and her education was picked up 


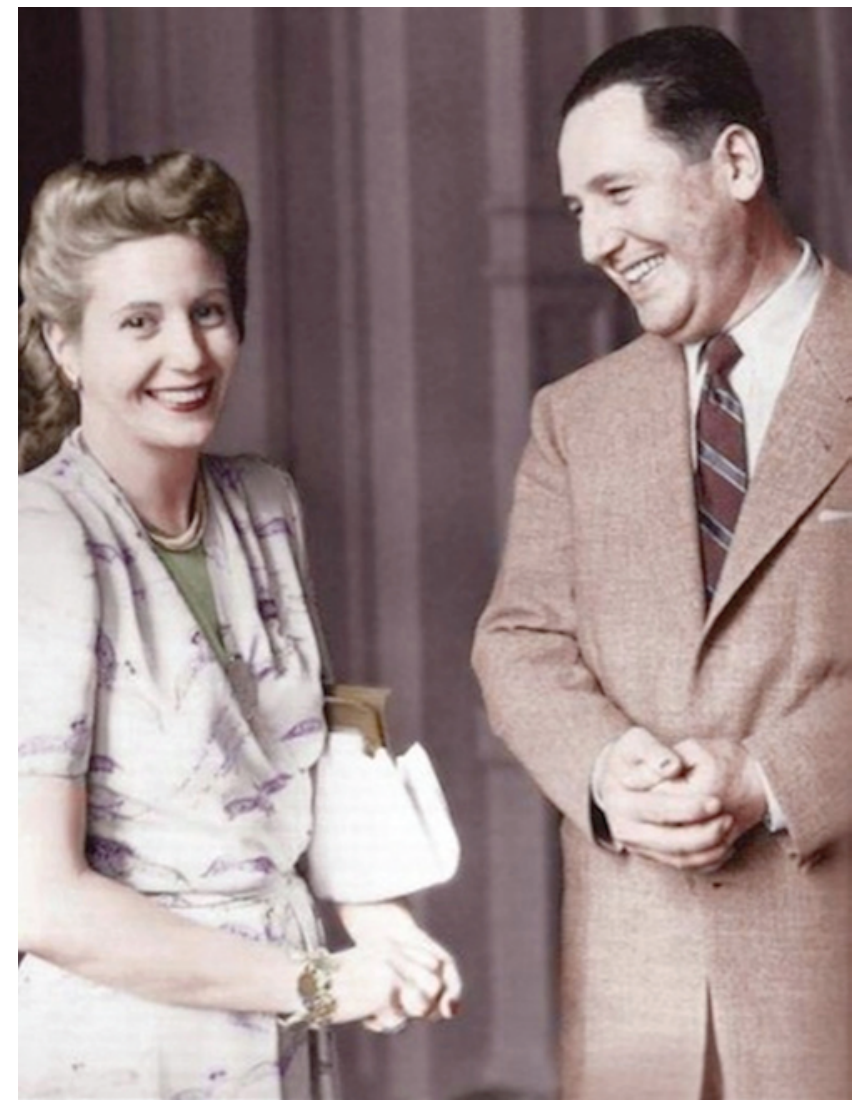

FIG. 1. Juan and Eva Perón in Buenos Aires, Argentina, 1948. Photograph in public domain.

along the way from the street and from playing roles of famous women as an actress. He was cold, collected, and lacking in affection, but steady under pressure. As a military man he was cautious, calculating, and very conscious of the power of church and army. In contrast, she was emotional and quick to anger, a firebrand. She had deep-seated resentments and anger that was manifested daily through her harangues against her opponents, the landowners and the "oligarchs," but both Juan and Evita enjoyed luxury and spoke about their sensitivity and love for the poor and dispossessed. However, Evita carried it to an extreme, deliberately placing herself close to the sick and receiving in her office throngs of paupers. He detested poverty and illness (Fig. 3).

\section{Evita's Illness and Downfall}

In September 1951, a cervical biopsy showed that Evita had advanced cervical cancer, and in November 1951 this diagnosis was confirmed by Dr. George Pack from New York Memorial Hospital, who secretly performed a total hysterectomy followed by a bilateral salpingo-oophorectomy in Buenos Aires. Although Evita appears to have been unaware of her diagnosis, she must have felt her life was ending. She suffered from generalized weakness, fatigue, and pain, and acted as if she knew there was little time for her to carry on with her life's program. Evita became more and more belligerent, and she incited violence. Her last public speech, delivered on May 1, 1952, Labor Day

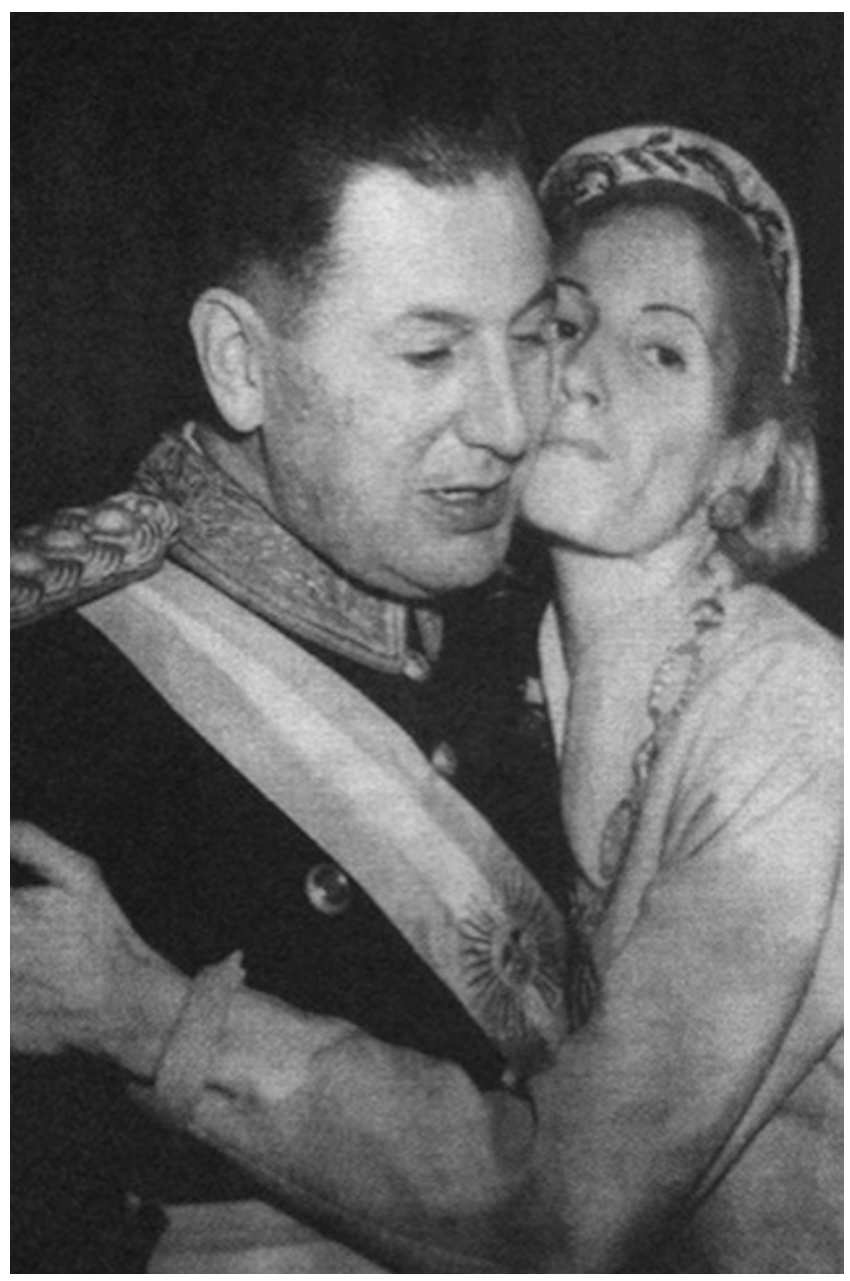

FIG. 2. Juan and Eva Perón in Buenos Aires, Argentina, early June 1952. Photograph in public domain.

in Argentina, was a call against her enemies. She also dictated a 79-page document, "My Message," showing evidence of her belligerence and violent state of mind. She spoke about the "enemies of the people" who were "insensitive and repugnant," and "as cold as toads and snakes." She exalted the "holy fire of fanaticism." She was "against those imbeciles" who called for prudence. She ordered the people of Argentina to "fight the oligarchy." In 2012, the Argentine Congress, in open session, accepted this document as the true political testament of Eva Perón. ${ }^{16}$

In September 1951, from her sick bed while undergoing intravaginal radium brachytherapy, Evita purchased 5000 automatic pistols and 1500 machine guns from Prince Bernhardt of the Netherlands, to arm the workers of the trade unions and form workers' militias. She also bought a huge quantity of ammunition and paid for it with cash from the Eva Perón Foundation. A select group of officers and noncommissioned officers of unquestionable loyalty started training the workers in northeastern provinces of Argentina. This was done without her husband's knowledge, and it revealed a particularly authoritarian streak with a tendency toward violence against anyone she perceived as an enemy. More than 1000 men and women trained in the Cerrito Island in the Province of El Chaco 


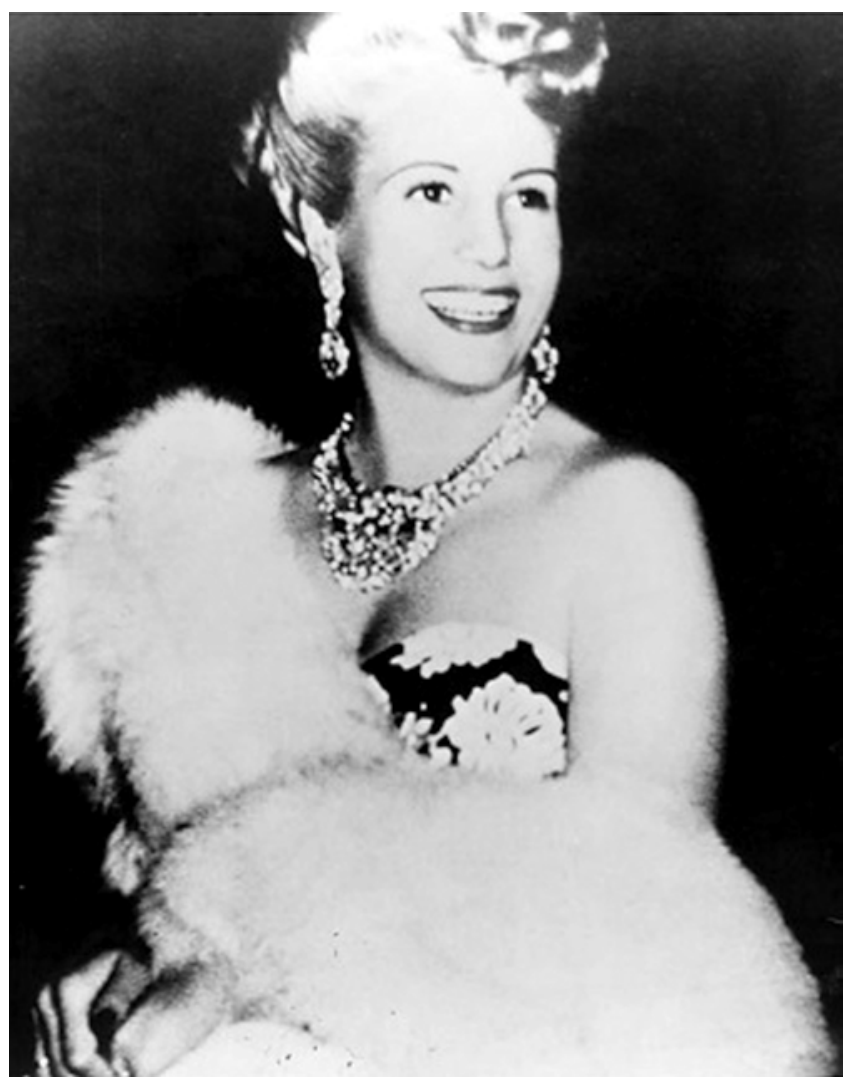

FIG. 3. Evita, 1950. Photograph in public domain.

under the leadership of Governor Felipe Gallardo. When Perón learned about it, he did not hide his discontent, and after Evita's death, he ordered the weapons to be placed in a military arsenal, the Esteban de Luca, for use by the National Gendarmerie. ${ }^{2,3}$

There are many accounts about Perón not visiting his wife's sick bed and showing disgust. He was bothered by her complaints, by the smell from the secretions, and by everything that had to do with wound care and dressing changes. Perón was concerned about her loyal followers and spied on them. He was also afraid of his former classmates, colleagues, and friends in the military, who had furiously opposed Evita's role in the government. His fears were well founded. There was a failed attempt to depose him in 1951 and he eventually had to face two major uprisings in 1955. The one of June 1955 was bloody, when navy aircraft bombed the Plaza de Mayo causing hundreds of deaths and casualties. The September 1955 uprising resulted in Perón being ousted from power. Feuds between different Peronist groups in 1952 exploded in the 1970s, by which time Perón, his government, and his party, had absorbed Evitism into their political ethos. Argentina's troubled history during the 1970 s, and even to the present, confirms that the 1952 fears of violent civil unrest and war between the two factions of the Peronist party, and also between Peronists and anti-Peronists, were accurate. ${ }^{23}$

\section{Dr. James Poppen and Prefrontal Lobotomy}

Through Dr. Gerwin Neumann, a former associate of

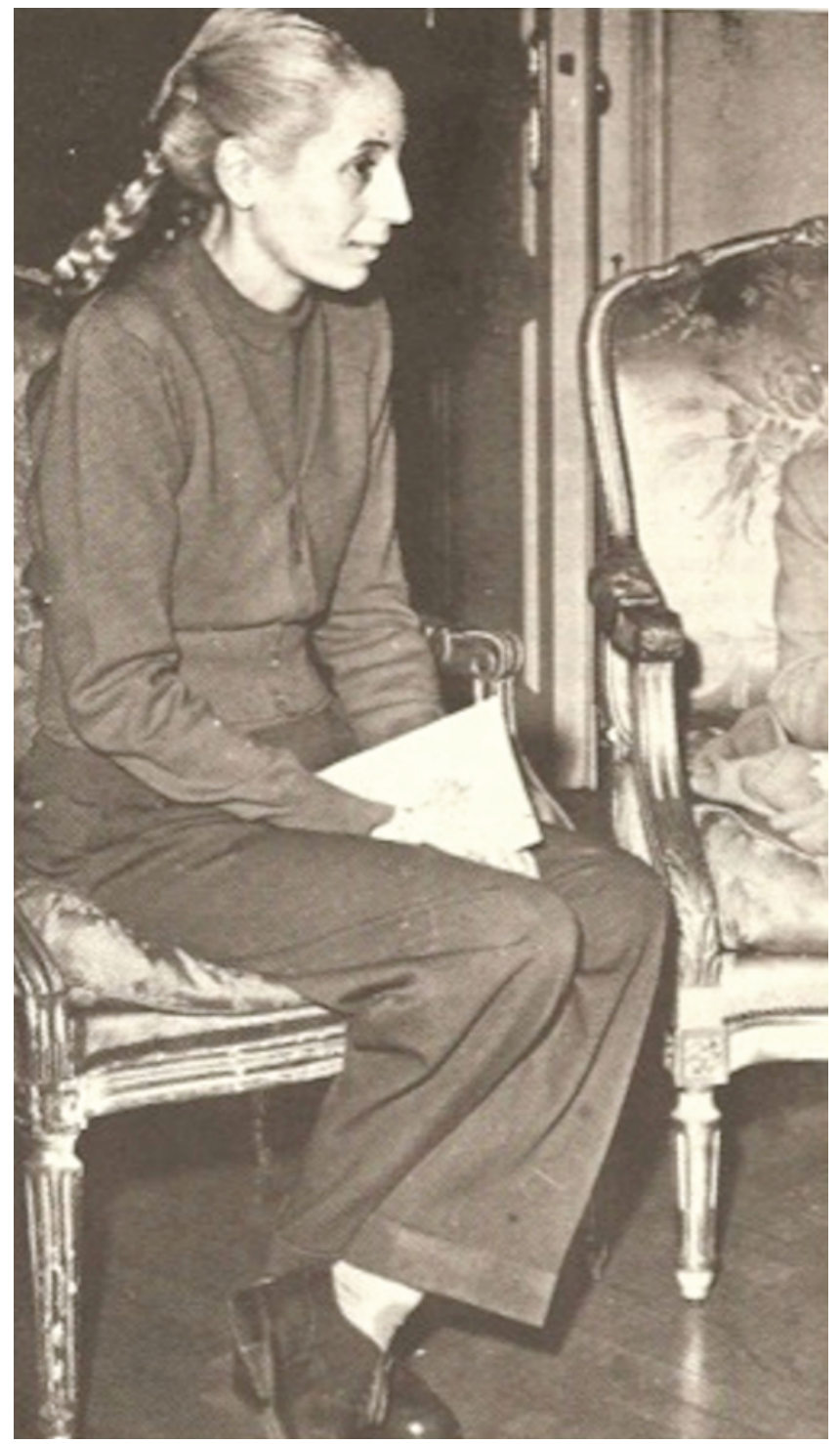

FIG. 4. Evita, end of June 1952. Photograph in public domain.

Dr. James Poppen, my colleagues and I contacted Manena Riquelme, RN, Poppen's former scrub nurse and confidante. Ms. Riquelme, born and raised in Chile, was interviewed in Santiago as part of this investigation. ${ }^{3}$ She confirmed that Dr. Poppen performed a prefrontal lobotomy on Evita in 1952, and she disclosed extraordinary and dramatic information that he also performed the operation of prefrontal lobotomy on about half a dozen prisoners in Buenos Aires, at Perón's request. She thought Poppen did it to "practice" before operating on Evita, and that he did not appear to have questioned the indications. She stated that Dr. Poppen was troubled by his role in Evita's treatment and surprised by her quick postoperative decline and early death. Evita basically stopped eating after the lobotomy (Fig. 4). The surgery took place without informed consent, and most likely in a back room of the presidential palace outfitted as an operating theater. ${ }^{3}$ It was probably done in the middle of the night, and with the highest level of concealment. Dr. Poppen confided to Dr. Yancey Beamer 


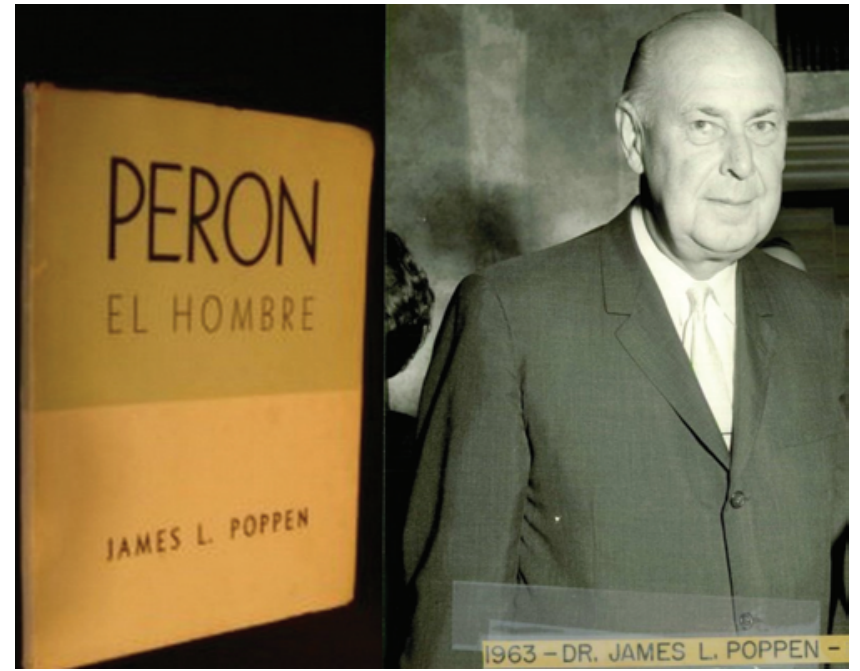

FIG. 5. Dr. James L. Poppen, 1963. Photograph from personal collection of Dr. Daniel E. Nijensohn.

that as a result of heightened security, he had to accept the presence of armed guards in the operating room (Y. Beamer, letter to Dr. Daniel E. Nijensohn, personal collection, July 18, 2012) (Figs. 5-8).

Prefrontal lobotomy (Fig. 9) was advocated for control of aggression and behavior/personality modification in the United States in 1952. The surgery was done on patients with "undesirable habits" to make them "quiet, placid and uncomplaining."1,6 A new "malleability" would ensue and the operation would be indicated for patients who were "difficult to manage." 7,8 It was done routinely in the American state prison system, such as in Vacaville and Atascadero in California. ${ }^{6}, 12$ Mark Vernon, Frank Ervin, and William Sweet advocated psychosurgery for violent behavior. ${ }^{21,22}$ Both William Scoville and José Delgado in Connecticut proposed "physical control of the mind," including psychosurgery, for the control of domestic and international violence in the political sphere. ${ }^{4,19}$ Walter Freeman, championing psychosurgery, stated that lobotomy was "the ideal operation for use in crowded state mental hospitals with a shortage of everything except patients." 7,8 The procedure became the operation of choice for treatment of "intractable and uncontrollable aggression, independent of any brain disease." 6,12

Many questioned the ethical and political implications of these "pacifying" operations, and psychosurgery was eventually seen as a particular menace to vulnerable individuals, particularly mental patients, captive children in state institutions, and incarcerated adults in state prisons. The use of psychosurgery for political means was seen as a specific potential menace, since it was used on political prisoners and dissidents in totalitarian societies and regimes. ${ }^{1,9,12,20}$

\section{Conclusions}

Fatal illness, intractable pain, and increasing anxiety, agitation, and belligerence were present at the end of the life of Eva Perón, Evita. She died at the end of July 1952 from metastatic cervical uterine cancer, and from appar-

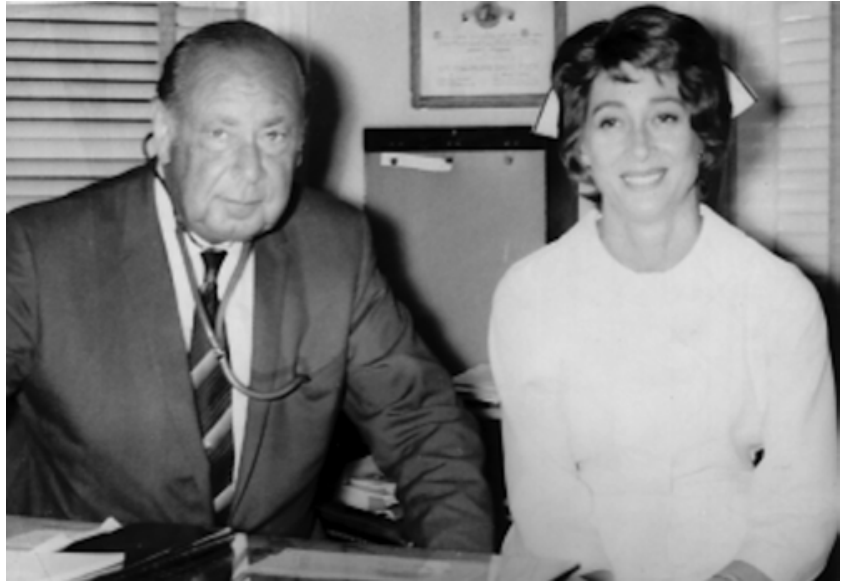

FIG. 6. Dr. James L. Poppen and Manena Riquelme, RN. Lahey Clinic, Boston, MA, USA, 1965. Photograph from personal collection of Dr. Daniel E. Nijensohn.

ent side effects of a prefrontal lobotomy performed in June 1952 in Buenos Aires. It was a time of terror, threats, and fights between the left and right wings of the Peronist party and between Peronists and anti-Peronists. It was also a time of enforced state secrets, secrecy mandated by the Hippocratic oath, lies, deceit, and misinformation. There was political turbulence, palace intrigue, and fights among the members of the medical team treating Evita. It was also a time of nationalism and dislike of foreign intrusion, especially from US physicians and surgeons. This contributed to the secrecy and the silence about the events.

George Udvarhelyi's declarations in 2005 opened up the possibility of studying this chapter in the history of medicine in Argentina. Prefrontal lobotomy was the standard of care, and although bizarre, it was the treatment (of last choice) in 1952 for the cancer-related intractable pain Eva was suffering from. However, we found enough evidence to confirm that the prefrontal lobotomy performed on her by Dr. James L. Poppen was done for behavior/

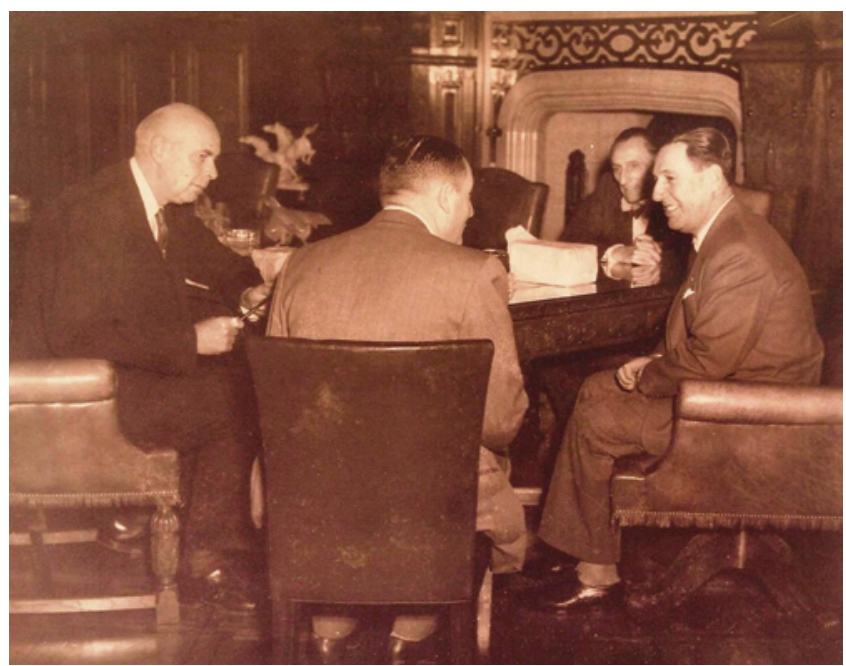

FIG. 7. Dr. James Poppen, President General Juan Perón, Dr. Ricardo Finochietto, and Dr. David Fairman. Casa Rosada, Buenos Aires, Argentina, late June 1952. Photograph from personal collection of Dr. Daniel E. Nijensohn. 


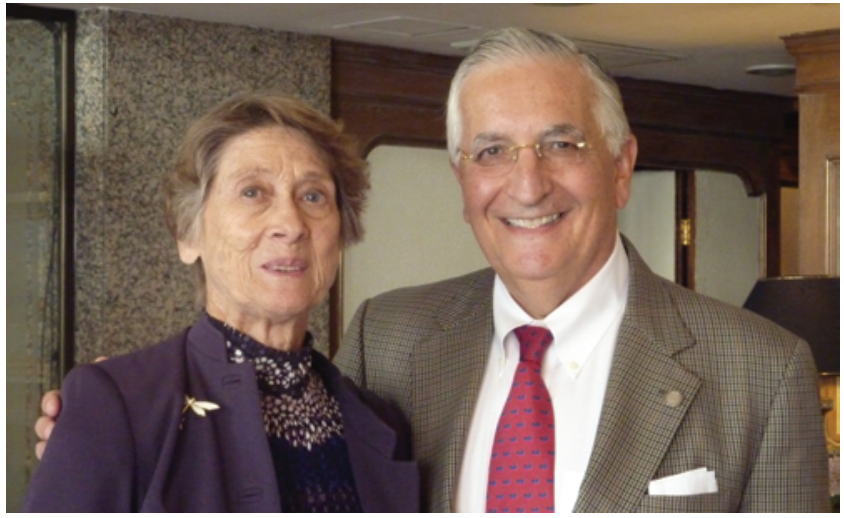

FIG. 8. Manena Riquelme, RN, and Dr. Daniel E. Nijensohn, Santiago de Chile, August 2012. Photograph from personal collection of Dr. Daniel E. Nijensohn.

personality modification in addition to pain control. The likelihood that the surgical procedure was part of a sinister political conspiracy that was orchestrated by the then President of Argentina, Juan Perón, and that ended up involving Dr. James L. Poppen, poses serious questions regarding medical professionalism and the ethics of neuroscience. Informed consent, service to the patient and not to the state, and avoidance of involvement in complicated political struggles must be the guiding principles of our daily neurosurgical practice. "Knowledge of the past is prerequisite to understanding the present" and "the business of serious historians is not to create comfortable myths, but to destroy them, or at least to correct them."'10

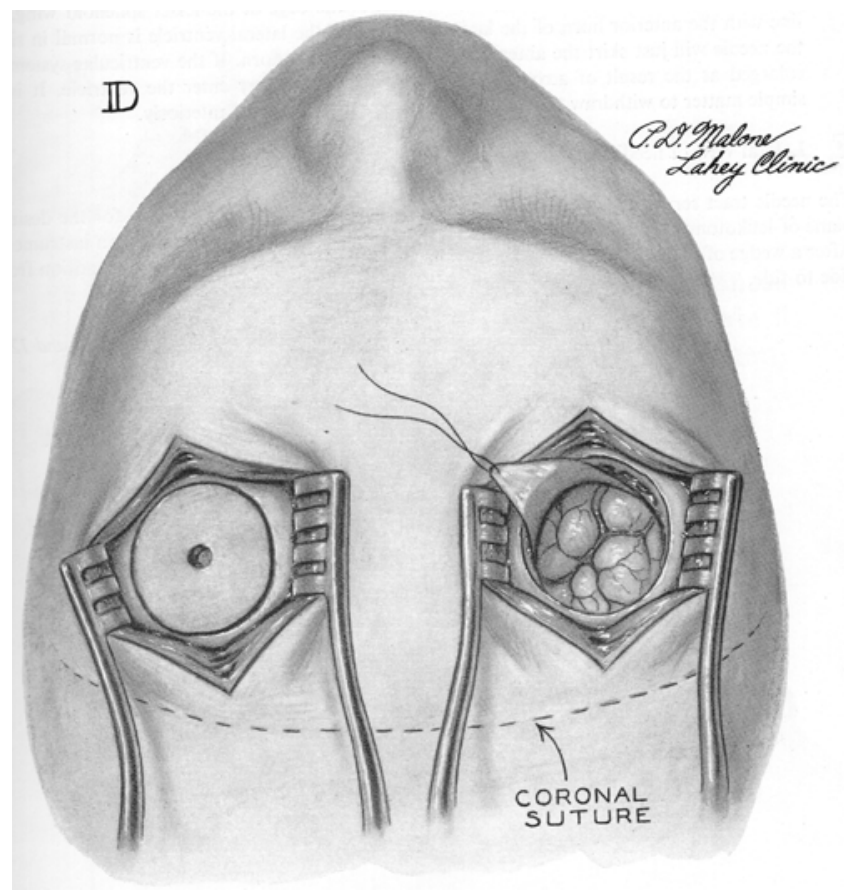

FIG. 9. Bilateral frontal trephinations for bilateral prefrontal lobotomy, superior approach. Reproduced with permission from Poppen JL: Technic of prefrontal lobotomy. J Neurosurg 5:514-520, 1948.

\section{References}

1. Breggin PR: Psychosurgery for the control of violence: a critical review, in Fields W, Sweet WH (eds): Neural Basis of Violence and Aggression. St Louis: Warren H. Green, 1975, pp 350-378

2. Castro N: Los Últimos Días de Eva. Historia de un Engaño. Buenos Aires: Vergara, 2007

3. Castro N: Los Últimos Días de Eva: Historia de un Engaño, ed 2. Buenos Aires: Sudamericana, 2014

4. Delgado JMR: Physical Control of the Mind: Toward a Psychocivilized Society. New York: Harper, 1969

5. Dynes JB, Poppen JL: Lobotomy for intractable pain. J Am Med Assoc 140:15-19, 1949

6. Faria MA: Violence, mental illness, and the brain-a brief history of psychosurgery: Part I, from trephination to lobotomy. Surg Neurol Int 4:49, 2013

7. Freeman W: Prefrontal lobotomy in the treatment of pain. Postgrad Med 5:375-379, 1949

8. Freeman W, Watts JW: Prefrontal lobotomy; indications and contraindications. Arch Neurol Psychiatry 60:97-100, 1948

9. Heller AC, Amar AP, Liu CY, Apuzzo ML: Surgery of the mind and mood: a mosaic of issues in time and evolution. Neurosurgery 59:720-739, 2006

10. Howard M: The Lessons of History. New Haven: Yale University Press, 1991

11. National Commission for the Protection of Human Subjects of Biomedical and Behavioral Research: The Belmont Report. Rockville, MD: United States Department of Health and Human Services, 1979 (www.hhs.gov/ohrp/human subjects/guidance/belmont.html) [Accessed April 30, 2015]

12. Nijensohn DE, Goodrich I: Psychosurgery: past, present, and future, including prefrontal lobotomy and Connecticut's contribution. Conn Med 78:453-463, 2014

13. Nijensohn DE, Savastano LE, Kaplan AD, Laws ER Jr: New evidence of prefrontal lobotomy in the last months of the illness of Eva Perón. World Neurosurg 77:583-590, 2012

14. Nijensohn DE, Savastano LE, Kaplan AD, et al: [New contributions on the treatment of pain, anxiety and agitation in the medical case of Eva Duarte Perón. Functional antalgic neurosurgery in 1952.] NeuroTarget 6:6-22, 2011 (Span)

15. Nijensohn DE, Laws ER Jr, Savastano LE: Homenaje a George B. Udvarhelyi, 1920-2010. NeuroTarget 6:5-10, 2011

16. Perón E: Mi mensaje. Página 12. July 29, 2012. (http://www. pagina12.com.ar/diario/contratapa/13-199802-2012-07-29. html) [Accessed April 30, 2015]

17. Perón J: Cómo conocí a Evita y me enamoré de ella, in Los Libros del Exilio. Buenos Aires: Corregidor, 1966

18. Poppen JL: Technic of prefrontal lobotomy. J Neurosurg 5:514-520, 1948

19. Scoville WB: Selective cortical undercutting as a means of modifying and studying frontal lobe function in man; preliminary report of 43 operative cases. J Neurosurg 6:65-73, 1949

20. Valenstein ES: Great and Desperate Cures: The Rise and Decline of Psychosurgery and Other Radical Treatments for Mental Illness. New York: Basic Books, 1986

21. Vernon M, Ervin F: Violence and the Brain. New York: Harper \& Row, 1970

22. White J, Sweet WH: Pain and the Neurosurgeon. Springfield, IL: Charles Thomas, 1969

23. Zanatta L: Eva Perón, una Biografía Política. Buenos Aires: Sudamericana, 2011

\section{Correspondence}

Daniel E. Nijensohn, Department of Neurosurgery, Yale University, 333 Cedar St., New Haven, CT 06510. email: nijensohn@aol.com. 